\title{
Assessment of river Yamuna and groundwater interaction using isotopes in agra and mathura area of Uttar Pradesh, India
}

\begin{abstract}
Yamuna river water quality has been deteriorated from Delhi onwards mainly in Agra and Mathura areas of Uttar Pradesh due to discharge of large quantities of untreated or partially treated wastewater into the river. Groundwater is also saline in these areas. Thus, the resultant poor water quality could worsen the problems of portable water supply to rapidly growing population of these areas. Groundwater and river water respectively is the main drinking water source in Mathura and Agra. Therefore, there is need to investigate the quality of bankside groundwater and surface water in Mathura and Agra as potential source of drinking water and also to assess the interaction between Yamuna river and groundwater. Keeping in view the above points, present study was carried out to assess river Yamuna and -groundwater interaction using isotope in the Agra and Mathura area of Uttar Pradesh, India. Samples of river and groundwater were collected from hand pumps/bore wells along the periphery of the Yamuna River. Analyses of the electrical conductivity (EC), temperature and isotopic composition $(\delta \mathrm{D})$ demonstrated that the groundwater is highly influenced by the river Yamuna. Groundwater containing seepage component is indicated by low temperature, low EC and depleted isotopic $(\delta \mathrm{D})$ composition. The influence of river on groundwater is found to decrease with the increasing distance from the river. The contribution of river water to the groundwater is more in Mathura as compared to Agra.
\end{abstract}

Keywords: Isotopes, Groundwater, Yamuna, Agra, Mathura
Volume I Issue 3 - 2017

\author{
Gopal Krishan,' Surjeet Singh,' Anupma \\ Sharma,' Cornelius Sandhu, '2 Sumant Kumar,' \\ Kumar CP,' Suman Gurjar' \\ 'National Institute of Hydrology, India \\ ${ }^{2}$ University of Applied Sciences (HTW), Germany
}

Correspondence: Gopal Krishan, National Institute of Hydrology, India, Email drgopal.krishan@gmail.com

Received: August 30, 2017| Published: October 06, 2017

\section{Introduction}

With an increase in demand of water in domestic, agricultural and industrial sectors due to ever increasing population, the discharge of various wastes in receiving water have also increased. Groundwater is the largest fresh water resource and considered to be the safe for drinking purposes among all water resources. For many communities groundwater may be the only economically viable option for drinking. However, this resource has also been polluted due to a variety of land and water-based human activities. Yamuna River is a major source of irrigation to the rural and semi-urban areas of Agra and Mathura. Several researchers reported that large quantities of impartially to partially treated domestic and industrial wastewater are discharged into the Yamuna River between Delhi to Agra city deteriorating the river water quality. ${ }^{1-3}$ It is need of an hour to investigate the quality of bankside groundwater and surface water in Mathura and Agra as potential source of drinking water and also to assess the interaction between Yamuna river and groundwater. Usually, management of surface water or groundwater resources has focused on considering them to be separate entities while with the development of land and water resources, notable changes were observed in quantity and quality of these resources. Generally, it is seen that all surface water features (rivers, lakes, reservoirs, wetlands, and estuaries) interact with groundwater in many forms. In several situations, the surface water body is a source of groundwater recharge or vice versa as pumpage of groundwater can deplete water in streams, lakes, or wetlands ${ }^{4,5}$ and contaminated surface water can cause degradation of groundwater quality. Thus, effective land and water management requires a clear understanding of the linkages between groundwater and surface water as it applies to any given hydrologic setting. Isotopic tracers can provide information on hydrograph separation on the fraction of surface water in groundwater or vice versa due to different isotope composition of both the sources. ${ }^{6}$ Generally, to separate the stream flow components, mixing models ${ }^{7}$ are applied however, numerous applications under different hydrological settings using various tracers have been documented ${ }^{7-12}$ and differences in concentrations of environmental tracers help in quantify groundwater recharge as stable hydrogen and oxygen isotopes of groundwater are generally less enriched than surface water. ${ }^{13-15}$ The interactions between groundwater and surface water, can be found using geochemical such as alkalinity, ${ }^{16}$ electrical conductivity ${ }^{17}$ and isotopic tracers such as isotopes of radon, ${ }^{8}$ chlorofluorocarbons, ${ }^{10,11}$ strontium, ${ }^{18}$ and radium. ${ }^{19}$ In the present study to assess the interaction of Yamuna River and groundwater of Agra and Mathura, the technique of stable hydrogen isotope was used.

\section{Study area}

The study area forms part of Yamuna River Basin. Yamuna River has a $580 \mathrm{~km}$ long stretch between Wazirabad Barrage in Delhi and its confluence with Chambal River near village Panchnada wherein river water is highly polluted. Agra and Mathura are two prominent cities situated on the Right Bank of Yamuna River within this stretch. The drinking water supply for both of these cities is in a critical condition for quantitatively it is insufficient and qualitatively unsuitable. On one hand Yamuna River water is affected by physical, chemical and microbiological pollution and on the other hand groundwater has very high Total Dissolved Solids (TDS). The objective of the present 
study is to observe the surface water contribution to groundwater quantitatively and qualitatively, on pumping the groundwater through the groundwater structures located closer to the bank beyond the Highest Flood Level (HFL) and accordingly the study area has been specified. The study area includes three cross-sections across YamunaRight-Bank (YBR), one cross-section YBR each at Agra and Mathura and groundwater sampling points safely off the Yamuna River course where River-Water and groundwater mixing is not expected. These sections and sample locations are shown in Figure 1 and their details are given in Table 1. Agra and Mathura both have semi-arid climatic conditions. The normal annual rainfall, at Agra, is $679 \mathrm{~mm}$, spread over 37 rainy days. The normal annual rainfall at Mathura is less than Agra which is $544 \mathrm{~mm}$ and spread over 32 rainy days. The area around the selected sections and sample collection points exhibits plain topography with a gentle slope towards Yamuna River which shows effluent conditions except during the monsoon period. Geologically the area is represented by alluvium of Holocene and recent age. The alluvium is deposited on the rocks of Super Vindhayan Group of
Proterozoic age. The alluvium as exposed at Agra and Mathura is fine grained and greyish white in color. It is porous and permeable and hence forms good aquifers.

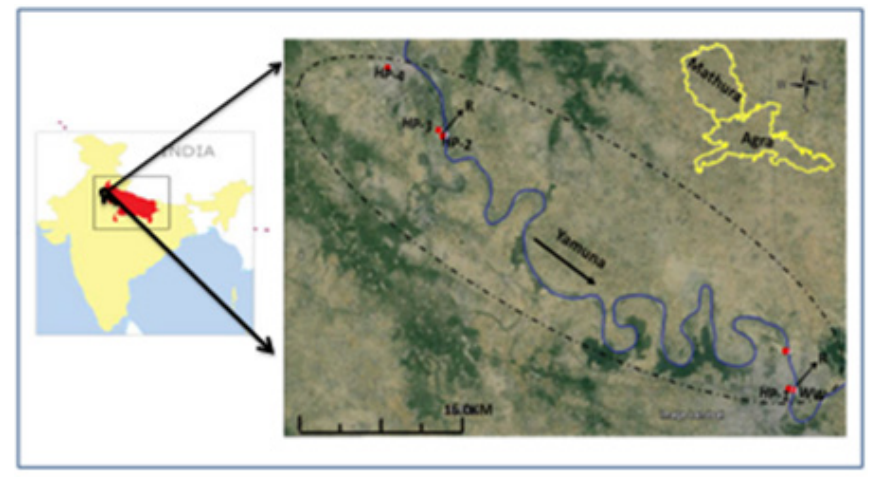

Figure I Study area showing sampling locations.

Table I Sampling details

\begin{tabular}{|c|c|c|c|c|c|}
\hline S. No. & Location/ ID & Depth & Distance from river $(\mathrm{m})$ & Latitude & Longitude \\
\hline I & Water Works (WW), Jiwani Mandi-A*/WW-Agra & $\begin{array}{l}\text { 20/ Ground } \\
\text { water }\end{array}$ & 140 & 27.20327 & 78.03197 \\
\hline 2 & Water Works, Jiwani Mandi-A*/R-Agra & I5/River & 200 & 27.20392 & 78.03162 \\
\hline 3 & River-Water Works, Jiwani Mandi-A*/ HP-I-Agra & -/ River & - & 27.20298 & 78.03335 \\
\hline 4 & River-Gokul Barrage-M*/R2-Mathura & -/ River & - & 27.44361 & 77.7139 \\
\hline 5 & Gokul Barrage itself-M*/HP-2-Mathura & $25 /$ Ground water & 30 & 27.44344 & 77.71367 \\
\hline 6 & Water Works-M*/HP-3-Mathura & $25 /$ Ground water & 615 & 27.44742 & 77.70939 \\
\hline 7 & Nagar Palika Parishad-M*/HP-4-Mathura & 25/ Ground water & 7544 & 27.50253 & 77.6652 \\
\hline
\end{tabular}

$A^{*}$, Agra; $M^{*}$, Mathura.

\section{Methodology}

To assess the surface water-groundwater interactions, samples from river water and groundwater from different depths were collected. To ensure representative sampling from the aquifer, the groundwater was flushed adequately or till constant $\mathrm{pH}$ and $\mathrm{EC}$ was achieved. Then the water samples $(500 \mathrm{ml})$ were collected in air/water tight polypropylene (plastic) bottles after rinsing the bottles by the groundwater that is to be sampled. The sample bottles were stored in refrigerated conditions to check fractionation of samples due to evaporation. Stable isotopes $(\delta D)$ are analysed on DI-IRMS (Dual inlet isotope ration mass spectrometer) with the minimum error limit within $\pm 1 \%$. The isotopic analyses $(\delta \mathrm{D})$ of collected water samples are done by standard equilibration method in which water samples are equilibrated with $\mathrm{H}_{2}$.

\section{Results and discussion}

Groundwater containing seepage component is indicated by low temperature, low EC and depleted isotopic $(\delta \mathrm{D})$ composition (Table 2 ). Due to the conservative nature of stable isotopic compositions in water and hardly any affect by water-rock mineralization under normal conditions,${ }^{20,21}$ the isotopic variations may occur in the periphery of river as a consequence of concentration variations in the input such as rainfall and river water. ${ }^{22}$ The $\delta \mathrm{D}$ values of the river water and groundwater samples collected in September 2015 shown in Table 2 giving accurate information on the input signal. These samples are well distributed illustrating that surface and groundwater from the shallow Quaternary aquifer most probably originate from present-day precipitation. The $\delta \mathrm{D}$ values enriched from $-53.81 \%$ to- $47.51 \%$ in Yamuna water from Mathura to Agra due to evaporation effect (Table 2 ). These show that the heavier isotopes were enriched in river water in the upstream, which resulted mostly from evaporation where these samples were collected (Figure 1). Isotopic composition of river water was mostly negative. It could be due to precipitation with lighter isotopes. Signatures of both of the groundwater samples at Agra (WW and HP-1) indicate that the sample HP-1 (-57.21\%) was depleted as compared to WW (-50.54\%), possibly indicating that the riverbankaquifer water may originate from a mixing of original groundwater and river water with more depleted isotope values and HP-1 is located at more distance $(200 \mathrm{~m})$ than the WW $(140 \mathrm{~m})$. The transitional wells of Water Works Agra (WW) and Water Works Mathura (HP3) both each at a distance of 140 and $615 \mathrm{~m}$, respectively from the river, seemed to be closely connected to the nearest river water as the groundwater had similar trends of stable isotope signatures with the river. That is because of the recharge from river water via bank infiltration relatively depleted $\delta \mathrm{D}$ signatures. The isotopic value of the groundwater sample of HP-4 is more enriched and higher EC values indicating the anthropogenic effects with almost no signatures 
of river water are found at a distance of 7544 meters from river. The composition of groundwater at these places can be described as a mixture of two possible sources, including groundwater from the regional system, and river water. Although one sample of observation seems to be less satisfactory in detecting groundwater recharge, it can provide information on the fraction of river to groundwater recharge for a specific period of time. When these water sources are considered as end members to the groundwater at HP-1 and HP-2 at Agra and Mathura, respectively, it is possible to estimate mixing proportions between the waters using a mass-balance approach. ${ }^{22-24}$ The resulting contribution percentages are more than $68 \%-90 \%$ using $\delta \mathrm{D}$, at Agra and Mathura, respectively which suggests groundwater is composed of approximately more than $68 \%-90 \%$ river water at Agra and Mathura, respectively using the isotope method.

Table 2 Isotopic and physico-chemical characteristics of water samples

\begin{tabular}{lllllll}
\hline S. No. & Sample code/id & Source & ph & ECuS/cm & Water temp. $\left({ }^{\circ} \mathbf{C}\right)$ & $\delta \Delta(\mathbf{0})$ \\
\hline I & WW-Agra & GW* $(140 \mathrm{~m}) * *$ & 6.99 & 1432 & 29.5 & -50.54 \\
2 & RIAgra & RIVER & 9.45 & 1152 & 35 & -47.51 \\
3 & HP-I-Agra & GW $(200 \mathrm{~m})$ & 6.87 & 1755 & 27.8 & -57.21 \\
4 & R2Mathura & RIVER & 8.95 & 1435 & 37.4 & -53.81 \\
5 & HP-2 Mathura & GW $(30 \mathrm{~m})$ & 7.1 & 1423 & 29.2 & -62.45 \\
6 & HP-3 Mathura & GW $(615 \mathrm{~m})$ & 7.22 & 1506 & 28.8 & -53.93 \\
7 & HP-4 Mathura & GW $(7544 \mathrm{~m})$ & 6.79 & 2890 & 28.8 & -47.27 \\
\hline
\end{tabular}

*GW, Ground water; **Distance from river

\section{Conclusion}

Groundwater containing seepage component is indicated by low temperature, low EC and depleted isotopic $(\delta \mathrm{D})$ composition. The influence of river on groundwater is found to decrease with the increasing distance from the river. The contribution of river water to the groundwater is more in Mathura as compared to Agra. This study result could be useful in planning and management of the water resources of the study area by developing potential river bank filtration sites

\section{Acknowledgment}

Authors thank Director, National Institute of Hydrology and Dr Ghosh NC, Head Groundwater Hydrology Division, and Roorkee for all support and encouragement.

\section{Conflict of interest}

None.

\section{References}

1. Agarwal S, Trivedi RC. Ecological analysis of the River Yamuna-a functional approach in a diversified ecosystem in India. Large Rivers. $1995 ; 9(3-4): 405-426$.

2. Anil Agarwal. CSE Fifth Citizens' Report on the State of India's Environment (Part 1). Centre for Science and Environment.(CSE), India; 2002. p. 1-192.

3. Seth BL, Babu SSV. Sewage Canal: How to Clean the Yamuna. Centre for Science and Environment, India; 2007. p. 1-180.

4. Mac Donald AM, Bonsor HC, Taylor R, et al. Groundwater Resources in the Indo-Gangetic basin- Resilience to climate change and abstraction. British Geological Survey Open Report. 2015;1-51.

5. Mac Donald Alan, Bonsor Helen, Ahmed Kazi, et al. Groundwater depletion and quality in the Indo-Gangetic Basin mapped from in situ observations. Nature Geosciences. 2016;9:762-766.
6. Kendall C, Caldwell EA. Fundamentals of Isotope Geochemistry, in Isotope Tracers. In: Kendall C, McDonnell JJ (Eds), Catchment Hydrology, Elsevier Science, Netherlands; 1998. p. 1-49.

7. Pinder GF, Jones JF. Determination of the ground-water component of peak discharge from the chemistry of total runoff. Water Resources Research. 1969;5(2):438-445.

8. Krishan G, Rao MS, Kumar CP, et al.A study on identification of submarine groundwater discharge in northern east coast of India. Aquatic Procedia. 2015;4:3-10.

9. Carey SK, Quinton WL. Evaluating runoff generation during summer using hydrometric, stable isotope and hydrochemical methods in a discontinuous permafrost alpine catchment. Hydrological Processes. 2005;19(1):95-114.

10. Lapworth DJ, Mac Donald AM, Krishan G, et al. Groundwater recharge and age-depth profiles of intensively exploited groundwater resources in northwest India. Geophysical Research Letters. 2015;42(18):7554-7562.

11. Lapworth DJ, Krishan G, Macdonald AM, et al. Using Environmental Tracers to Understand the Response of Groundwater Resources in NW India to Sustained Abstraction. Proc. of 41st International Conf. of International Association of Hydrogeologists on Groundwater: Challenges and Strategies, NERC Open Research Archive, Morocco; 2014.

12. Lapworth DJ, Krishan G, MacDonald AM, et al. Groundwater quality in the alluvial aquifer system of northwest India: new evidence of the extent of anthropogenic and geogenic contamination. Sci Total Environ. 2017;599-600:1433-1444.

13. Coplen TB, Herczeg AL, Barnes C. Isotope engineering-using stable isotopes of the water molecule to solve practical problems. In: Cook PG, Herczeg AL, Kluwer Boston (Eds.), Environmental tracers in subsurface hydrology, Springer, USA; 2000. p. 1-529.

14. Hinkle SR, Duff JH, Triska FJ, et al. Linking hyporheic flow and nitrogen cycling near the Willamette River-a large river in Oregon, USA. Journal of Hydrology. 2001;244(3-4):157-180. 
15. Yehdegho B, Rozanski K, Zojer H, et al. Interaction of dredging lakes with the adjacent groundwater field: an isotope study. Journal of Hydrology. 1997;192(1-2):247-270.

16. Rodgers P, Soulsby C, Petry J, et al. Groundwater-surface-water interactions in a braided river: a tracer-based assessment. Hydrological Processes. 2004;18(7):1315-1332.

17. Harvey FE, Lee, DR, Rudolph, et al. Locating groundwater discharge in large lakes using bottom sediment electrical conductivity mapping. Water Resources Research. 1997;33(11):2609-2615.

18. Debnath P, Mukherjee A, Rokade P, et al. Stable isotopes and major ion chemistry of discharging groundwater to the Bay of Bengal: implications to strontium flux. Goldschmidt Abstracts, Prague, Czech Republic, 2015 p. $1-681$.

19. Kraemer TF. Radium isotopes in Cayuga Lake, New York: Indicators of inflow and mixing processes, Limnology and Oceanography 2005;50:158-168.

20. McCarthy KA, McFarland WD, Wilkinson JM, et al. The dynamic relationship between ground water and the Columbia River: using deuterium and oxygen-18 as tracers. Journal of Hydrology. $1992 ; 135(1-4): 1-12$.
21. Gat JR. Oxygen and hydrogen isotopes in the hydrologic cycle. Annual Review of Earth and Planetary Science. 1996;24:225-262.

22. Kendall $\mathrm{C}$, McDonnell JJ. Isotope Tracers in Catchment Hydrology, Elsevier, Netherlands; 1998.

23. Christophersen N, Hooper RP. Multivariate analysis of stream water chemical data: the use of principal components analysis for the endmember mixing problem. Water Resour Res. 1992;28(1):99-107.

24. Clark ID, Fritz P. Environmental Isotopes in Hydrogeology. Lewis Publishers, New York; 1997. p. 1-331.

25. Krishan G, Singh S, Sharma A, et al. Assessment of river quality for river bank filtration along Yamuna River in Agra-Mathura districts of Uttar Pradesh. International Journal on Environmental Sciences. 2016;7(1):56-67. 